\title{
Believing and Doing
}

Who are they? What do they believe? How do they make sense of the world? And what do they do? Asatru's path towards public recognition can be traced in the changing make-up of its adherents, in the continuities and changes of its core beliefs and practices, as well as in the attempts to contextualize one's own worldviews and rituals within one's respective social context. We can observe significant overlaps with other varieties of Neopaganism, Western esotericism and Wicca regarding conceptions of the divine; individual deities; the relations between humans, gods, and the world; as well as views on ritual and magic. Nevertheless, the continuities of religious ideas originating in völkisch contexts are still significant, albeit often unacknowledged or unnoticed. Such contradictions and controversies around basic beliefs are perceived as insignificant in Asatru today. This is due to the fundamental self-conception of Asatru as a non-dogmatic religion that leaves ample room for individual constructions of faith and allows for the relatively easy adaption of broader sub-cultural and mainstream currents.

\section{Finding Asatru}

Asatru is not a widespread phenomenon, with group membership usually ranging in the hundreds, often even less. Even if we allow for a certain extrapolation of individual practitioners or those practicing exclusively in loosely organized local or regional circles, the total number of Asatruers worldwide probably does not surpass 20,000 . The lack of reliable hard data makes it difficult to assess the membership's social background. In my interviews, it was not uncommon to hear complaints about social outsiders or misfits dominating other Asatru groups, as well as the claim that their own groups consisted of members from all strata of society. For Germany, Gründer observes that the average class and economic background of Asatruers is lower in racial-religious groups than in a-racist ones. In the case of the latter, more members come from middle-class environments, and hold college or university degrees, although they often work in insecure or low-paying jobs. ${ }^{1}$

1 Cf. Gründer, Blótgemeinschaften, 66f.

(C) KONINKLIJKE BRILL NV, LEIDEN, 2016 | DOI 10.1163/9789004309517_005

This is an open-access article distributed under the terms of the Creative Commons Attribution-

NonCommercial 3.o. Unported (CC BY-NC 3.o) License, http://creativeccommons.org/licenses/by-nc/3.969004309517 
In comparison, Scandinavian groups seem to consist mainly of members in fairly secure middle-class professions. ${ }^{2}$ Typically, the majority of members are between thirty and sixty years old. Many of them have previously passed through a stage of spiritual 'search' via several different religious communities or ideologies. Most groups have older members as well, who have been active in the movement for a longer time and tend to be in leading positions or at least have a degree of authority. The most significant deviation in the make-up of Asatru groups as compared to other alternative religions is gender distribution. Due to its cult of the warrior and Viking heroism, Germanic Neopaganism has traditionally been attractive to men, although the number of female members has been increasing in recent years. Today, the membership of the typical Asatru group is about one-third women.

What then are the stories Asatruers tell about how they came to be attracted to this religion? Almost all of the Heathens that I encountered in the 1980 s were motivated by strong affects against their own Christian backgrounds. Anti-Christian sentiments still drive many individuals and group policies. ${ }^{3}$ In accordance with a general decline of traditional church life's significance in Western societies, this motive has become less prominent in recent years. It remains in place in areas such as parts of rural Norway or the USA, where fundamentalist Christian churches are influential. Christian background or not, the most common story Asatruers tell is one of "awaking childhood memories." ${ }^{4}$ These memories are frequently connected with storybook adaptations of Norse mythology or with popular films and comics. Scandinavian Asatruers invoke school lessons about Eddic poetry and saga literature, which still today form part of the national curricula. For some, recollections of folk customs by parents, grandparents, or other older relatives play a role as well. ${ }^{5}$ These accounts indicate that many Asatruers attach great importance to the fact that their faith is connected to what they perceive as cultural roots transmitted through family and childhood experience. These accounts also suggest a sentiment many Asatruers share as well, the sense of "always having been Asatru."

2 My Norwegian interview partners reported unanimously that there was a curious predominance of people working in the IT and health sector.

3 For a more in-depth discussion see Chapter 5 .

4 This term was used by Kaplan, Radical Religion in America, 18, who made the same observation amongst American Asatruers already in the 199os.

5 Not only my own interviews, but also ones with prominent Asatruers published in the Danish journal Valravn over the years, show these results. 
Nevertheless, for most Asatruers, as for converts to other non-dominant religions, this feeling of "coming home"6 occurs only after a longer period of searching and examining other religious, esoteric, and philosophical traditions - a fact which explains the relatively high average age within most Asatru communities. ${ }^{7}$ For many, this includes a period within the Wicca milieu, for others, a phase of religious indifference or atheism. Many of the latter have been involved in popular cultural scenes of live re-enactment or role-playing. They are drawn to Asatru through a growing sense that cultural re-enactment and historical interest is not enough, but that spirituality is an important facet of their lives after all, and that "all humans have an inner religious need." 8

The final turn to Asatru is experienced differently from country to country. In Scandinavia, their 'coming home' is usually perceived as something rather undramatic, as the finding of an 'instinctive certainty'; as something that 'just feels right.' As Norse mythology and Viking history are considered integral parts of Norwegian, Danish, Swedish and Icelandic heritage, the turn to Asatru seems to require less elaborate explanation and feels more like a "natural consequence," as one Icelander put it. ${ }^{9}$ In the USA, many Heathens motivate their choice with their German or Scandinavian heritage and ancestry - a generally accepted paradigm in a country of immigrants in which many people are

6 In her "classic" presentation of the diverse Neopagan scene in North America from 1979 (revised editions appeared in 1986 and 2006) Margot Adler calls Paganism "a religion without converts." She builds her argument on such experiences of "coming home," of always having "had a religion, I just never knew it had a name" (Adler, Drawing Down the Moon, 13). Sían Reid, "A Religion Without Converts' Revisited. Individuals, Identity and Community in Contemporary Paganism," in Handbook of Contemporary Neopaganism, ed. James R. Lewis and Murphy Pizza (Leiden/Boston: Brill, 2009) "revisits" this thesis, distinguishing between a Christian, Paulinian model of conversion as "something that 'happens to' an individual" and a "new paradigm' of the activist conversion, the prototype for which is the 'seeker" (173). This model can be used to describe contemporary Pagan experiences of conversion. See also Gründer, Blótgemeinschaften, 96f, who observes a certain tension between a processual transformation of worldviews, an interpretive drift towards a polytheistic religious framework, and such "coming home" experiences, which are narrated as singular and concrete experiences.

7 Obviously, this does not mean that Asatru is necessarily the last stage in everybody's religious search, but from the data available to me it is impossible to assess the percentage of longterm versus short-term members. The impression given here - that a larger number of adherents tend to stay with Asatru for at least an extended period of time - might also have to do with the fact that the long-term active members tended to volunteer more frequently to be interviewed than less committed members.

8 See Interview $\mathrm{U}$.

9 Cf. Interview S. 
searching for their roots. Germans who choose to join more right-wing Asatru groups already have a fairly secure ideological conviction and understand their adoption of a Germanic religious framework as its logical consequence. ${ }^{10}$ For the growing number of German Asatruers who explicitly reject racial and ethnic paradigms, the turn to the Norse gods has not been unproblematic. It is often accompanied by considerable inner struggles resulting from the fact that German neo-Germanic Paganism up until the 1990s was strongly dominated by groups promoting a more or less overt racial esotericism. ${ }^{11}$ This might also be the reason why an astonishingly large number of German Asatruers present their being drawn to Norse mythology as a strong, but ultimately inexplicable and irrational inner pull. This is especially the case for outspokenly a-racist, politically critical Heathens who are looking for explanations for their own choices beyond any ethnic or racial criteria. ${ }^{12}$

A similar wish to demonstrate the sincerity and authenticity of one's own religious path might lie at the basis of another common narrative. A good number of Asatruers emphasize their having had liminal or mystical experiences occasioned by accidents, personal crises or similar, in which they directly encountered the presence of a deity. In my interview samples, such experiences were mostly conveyed by German Asatruers. However, Michael Strmiska and Baldur Sigurvinsson provide similar examples among North American Heathens. ${ }^{13}$

\section{Heathen Beliefs}

Most of my interview partners offered elaborate personal narratives about how they found Asatru and what it means to them. They were also quite articulate when it came to describing Asatru rituals and their worldview in general. In contrast, the question of how they perceive the Norse gods and their relationship to them proved difficult for many. Answers were frequently emphatic statements that concepts of the divine are so diverse and varied

10 Cf. Gründer, Blótgemeinschaften, $78 \mathrm{f}$.

11 It is hard to judge the extent to which such narratives are influenced by my position as a critical investigator of the field. My impression is that they emphasized these notions over other motives for my sake and in order to not be grouped among right-wing extremists, but that they at the same time were honest and sincere about them.

12 It is thus a sentiment that was especially shared by all members of Nornirs \&tt to whom I spoke.

13 Michael Strmiska and Baldur A. Sigurvinsson, "Asatru: Nordic Paganism in Iceland and America," in Modern Paganism in World Cultures. Comparative Perspectives, ed. Michael Strmiska (Santa Barbara, CA: ABC-Clio, 2005), 147, 155. 
within Asatru that no outsider could possibly understand them. Some also see it as a very personal and intimate question, which they are reluctant to answer. One German Heathen gave a particularly elaborate explanation typical of these widespread sentiments. It shows the variety of concepts within one person along with those concepts' indeterminability, and points to unresolved contradictions:

This is the question that I find the most difficult, and I am afraid to not be able to give a really satisfactory answer in this limited space, especially since my ideas about [the gods] are not one-dimensionally constant, but oscillating. Furthermore, it is impossible to communicate numinous experiences without distorting them through the limitations of the possibilities of linguistic expression. A personified concept is of course helpful and makes many things easier, and I often see them like that. At the same time, I am aware that such a limitation, which comes from our limited imagination, cannot do justice to them. In other moments, I see them as abstract, as the forces which hold the cosmos together, which let life germinate in spring and which are remote from human invocation. Then again, I think that I can feel their protective and directive force in my own life. Or maybe they are only aspects of my own psyche, which are inaccessible in normal consciousness, but can be experienced and helpful in liminal experiences and extraordinary situations? In general, I experience the deities as basic characters and basic qualities of the world which appear in the psyche as well as in nature. ${ }^{14}$

14 Interview N: "Diese [...] Frage empfinde ich als die schwierigste überhaupt, und ich fürchte, auf dem hier begrenzten Raum keine wirklich befriedigende Antwort geben zu können, zumal meine Vorstellungen über sie nicht eindimensional konstant sondern oszillierend sind. Zudem ist es unmöglich, Erfahrungen des Numinosen wiederzugeben, ohne sie dabei durch die Begrenzungen sprachlicher Ausdrucksmöglichkeit zu verbiegen. Eine personifizierte Vorstellung ist natürlich sehr hilfreich und macht vieles einfacher, und so sehe ich sie auch oft, während mir aber doch gleichzeitig bewusst ist, dass ihnen eine solche Einschränkung, die nur unserer begrenzten Vorstellungskraft entspringt, nicht gerecht werden kann. In anderen Momenten sehe ich sie eher abstrakt als die Kräfte, die den Kosmos zusammenhalten, in jedem Frühling wieder das Leben sprießen lassen und die menschlicher Anrufung fern stehen. Dann wieder meine ich, ihre schützende und bestimmende Kraft auch im eigenen Leben zu spüren. Oder sind sie vielleicht nur Aspekte der eigenen Psyche, die einem im Normalbewusstsein unzugänglich, in Grenzerfahrungen und Ausnahmesituation aber erfahrbar und hilfreich sind? Allgemein aber empfinde ich die Gottheiten als Grundcharaktere und Grundqualitäten der Welt, die in der Psyche ebenso wie in der Natur erscheinen." 
This Heathen goes on to explain that for him, humans and gods are inextricably connected to one another, as they are each an integral part of the world. However, when it comes to the question of whether the gods are an expression of a certain cultural heritage, he initially rejects this notion in order to later reaffirm a similar relation:

About gods and culture: On the one hand, I see the least connection there, because culture is purely a product of human communities. On the other hand, Asatru, as a reconstructionist religion, of course aims at a certain cultural integrity which is limited to the Germanic cultural sphere. But as Asatru for me is not based on theological hair-splitting, I have never found it necessary for myself to work out final answers to these questions. Nevertheless, I think that all humans experience the same forces, although they are modified by landscape and climate and called by different names. ${ }^{15}$

The statement about the lack of theological hair-splitting reflects a very common attitude among Heathens. It indicates that the implicit contradiction between irreconcilable elements, that are nonetheless perceived as equally necessary, are common in Asatru (and of course not only here), but that they are rarely openly addressed and usually evaded. This happens frequently through the almost dogmatic invocation of the notion that the fundamental nature of Asatru is its lack of dogmatism. Therefore, in spite of the variety of images and concepts of the deities, there is hardly any controversy around the 'right' concept.

However, it is possible to discern a general trend about how concepts of the divine have developed since Germanic Neopaganism's 'invention' in the early 2oth century. Adherents of a völkisch religion found the polytheistic nature of their ancestors' faith embarrassing, but nevertheless in accordance with the general attitudes of their time; they were naïve at best, objectionably primitive at worst. They thus followed different strategies to prove the superior,

15 Ibid.: "Zu Göttern und Kultur: Hier sehe ich einerseits am wenigsten Verbindung, da Kultur ein reines Produkt menschlicher Gemeinschaften ist. Andererseits aber bemüht sich Asatru als rekonstruktionistische Religion dabei natürlich um eine gewisse kulturelle und auf den germanischen Kulturraum beschränkte Integrität. [...] Da Asatru aber nicht von theologischen Spitzfindigkeiten geprägt ist, habe ich es für mich nie als notwendig empfunden, mir zu diesen Fragen endgültige Antworten erarbeiten zu müssen. Dennoch denke ich, dass alle Menschen dieselben Mächte erfahren, wenn auch landschaftlich und klimatisch modifiziert und unterschiedlich benannt." 
monotheistic nature of Germanic faith. ${ }^{16}$ Such negative attitudes toward polytheism changed in the 1970s. All the same, the assumption that the Germanic pantheon is a natural expression of the spiritual forces that guide the Germanic or Nordic peoples, or manifests the folk- or race-soul, remained firmly in place. This racial-religious idea is reminiscent of C.G. Jung's theory of archetypes; it is no coincidence that Jung's thought was and still is frequently referred to, not only by Germanic Neopagans, but in other Neopagan and alternative spiritual circles as well. ${ }^{17}$ The archetypal approach is easily combined with the idea that the gods are forces, active within nature and within humans themselves. As the above quote demonstrates, the combination of these three aspects - cultural heritage, psychological principle, and the force of nature - is still prevalent among contemporary Asatruers.

The archetypal approach has lost its dominant position since the 1990s. The German ethnicist VfgH's homepage makes this clear:

Traditional Germanic Heathenism is a polytheistic religion which does not see 'aspects' of an abstract divinity in the gods as do some esoteric systems. It does not reduce the diversity of their personalities to speculative phantoms as 'the god and the goddess' and it certainly does not psychologize them as 'archetypes' or diminish them to mere symbols. Gods and Goddesses really exist and are concrete, personal beings with individual personalities. ${ }^{18}$

16 German Faithlers would vehemently refute accusations of wanting to revive a primitive "Cult of Wotan" by making it clear that their religion had evolved from these roots into modern times and included the philosophies of all 'great German thinkers.' In accordance with theosophy and other contemporary neo-Gnostic schools, Ariosophists such as Guido von List avoided the problem of polytheism by distinguishing between an exoteric, polytheist 'Wotanism' for the broader masses, and a secret, monotheist 'Armanism' for the initiated higher warrior, king, and priest elites.

17 For Neopaganism in general, the renegade Jungian analyst and theorist James Hillman's ideas about archetypal psychology being polytheistic in nature had major significance. See e.g. Hillman's afterword in David L. Miller, The New Polytheism. Rebirth of the Gods and Goddesses, 2. ed., with a prefatory letter by Henry Corbin, appendix by James Hillman (Dallas, Tx: Spring Publications, 1981).

18 "Das traditionelle germanische Heidentum ist eine polytheistische Religion, die in den Göttern keine 'Aspekte' einer abstrakten Göttlichkeit sieht, wie es manche esoterischen Lehren tun, die Vielfalt ihrer Persönlichkeiten nicht auf spekulative Phantome wie 'den Gott und die Göttin' reduziert und sie schon gar nicht als 'Archetypen' psychologisiert oder zu bloßen Symbolen herabwürdigt. Götter und Göttinnen existieren tatsächlich und sind konkrete persönliche Wesen mit individuellen Persönlichkeiten.” ("Was sind Götter überhaupt," http://www.vfgh.de/, last accessed March 19, 2014). 
Increasingly, and with less obvious embarrassment, Asatruers speak about their gods as "real and mighty beings";19 as individual, independent entities with different powers and areas of responsibility; ${ }^{20}$ as "good friends" one can "relate to" and "ha[ve] a relationship with"; ${ }^{21}$ as parts of this world; and as complex, wise, and powerful beings who are "not omniscient." ${ }^{22}$

The trend toward a more 'strict' polytheism in recent years serves to delineate one's own religion against three tendencies that are seen as potentially problematic. The first is Christianity and other 'book religions,' which allegedly posit God as "an abstract, otherworldly, eternal, all-mighty being that hovers above the world and rules it from the outside, not a 'pure spirit' or moral authority that exclusively embodies the so-called good."23 The second is C.G. Jung's theory itself, whose concept of archetypes has come increasingly under attack for being too close to völkisch and racial thinking. ${ }^{24}$ The third is the more syncretistic Wicca movement, against which Asatru tries to posit itself as authentic and in accordance with original sources. ${ }^{25}$

One concept developed within German and Scandinavian scholarship of the 1920 and 30 s has survived up until today: the belief in a fulltrúi or patron deity. It can serve as an instructive example for the symbolic continuities as well as the ideological transformations within Germanic Neopaganism over the last hundred years. The term fulltrúi ${ }^{26}$ surfaces first in Icelandic medieval hagiographic manuscripts, where it is used to characterize patron saints. Later on, it appears in saga literature, describing a man's relation to a Pagan god, with whom he has an exclusive patron-subject relationship. It is likely that the

\footnotetext{
19 Gundarsson, Our Troth, vol. I, 131.

20 GardenStone, Germanischer Götterglaube. Asatru - eine moderne Religion aus alten Zeiten (Engerda: Arun, 2003), 43.

21 Interview $\mathrm{O}$.

22 Gundarsson, Our Troth, vol. I, 131.

23 "Was sind Götter überhaupt "(http://www.vfgh.de/, last accessed March 19, 2014): "Eine Gottheit im Heidentum ist kein abstraktes, jenseitiges, ewiges, allmächtiges Wesen, das über der Welt schwebt und sie von außen regiert, kein 'reiner Geist' und keine moralische Instanz, die ausschließlich das sogenannte Gute verkörpert."

24 This sentiment was voiced by a number of my Scandinavian interview partners. In its new edition of Our Troth (Gundarsson, Our Troth,vol. I, 100), Jung is even grouped as part of the völkisch movement. This change in the perception of Jung has to do with the publication of Richard Noll's controversial book The Jung Cult (Noll, The Jung Cult), which brought to light Jung's debt to völkisch ideology.

25 Cf. Gregorius, Modern Asatro, 200.

26 Incidentally, the term has moved into the modern Icelandic language as well, where it now means 'representative.'
} 
fulltrúi is a Christian imagination of what Pagans' relationships to their gods might have looked like. In these texts, it has predominantly literary functions. The popularization of the concept in the 1920 and 30 is related to the desire to prove the monotheistic, and thus superior, character of the original Germanic faith. It was posited as an alternative to Christianity and Judaism, as an "upright" form of religiosity, based not on the "fear of God, but an equal relation between man and god based on mutuality," ${ }^{27}$ corresponding with the freedom-loving mentality of the Germans. ${ }^{28}$ The imagined relationship of equality, and its often polemic, antithetical contrast to the alleged relation of submission and obedience ascribed to Christianity, has a significant persuasiveness for Asatruers worldwide. ${ }^{29}$

At the same time, an increasing number of Asatruers are by now aware of the tenuous link between their belief in a fulltrúi and the Old Icelandic sources from which the concept is derived. ${ }^{30}$ Here, as in other cases in which historical accuracy contradicts lived experience in Asatru, the latter is ranked higher in terms of importance. A participant in the Eldaring online forum summarizes this attitude:

The discussion is unnecessary in practice, because even though $\mathrm{x}$ scholars prove that an intimate relationship to a god/goddess is originally Christian, I know what I have experienced and felt. And that is what counts. ${ }^{31}$

27 Julia Zernack, "Fulltrúi," in Reallexikon der Germanischen Altertumskunde, ed. Heinrich Beck, Dieter Geuenich, and Heiko Steuer (Berlin/New York: Walter de Gruyter, 1996), 244.

28 This summary follows "Fulltrúi," in Reallexikon der germanischen Altertumskunde, ed. Heinrich Beck, Heiko Steuer, and Dieter Timpe (Berlin: de Gruyter, 1997).

29 This is probably also due to the spread of the concept by Swedish scholar Folke Ström, whose summarizing presentation of "Nordic Paganism" from 1967 serves, for many Scandinavian Asatruers, as an important source for the construction of their religion (Gregorius, Modern Asatro, 209, see also Folke Ström, Nordisk hedendom. Tro och sed $i$ förkristen tid, 2. ed. (Göteborg: Akademiförlaget, 1967)). According to the user "Bil" on www.asatrulore.org (last accessed March 19, 2014) American Asatruers have received the fulltrúi or 'patron' concept from Harry Harrison's alternative historical trilogy The Hammer and the Cross, published in 1993. For the significance of these novels see Chapter 9 .

30 See the contributions by "Bil" on www.asatrulore.org (last accessed March 19, 2014), who draws attention to the fact that the concept lacks historical support and is considered a syncretistic construction, influenced by Christian and New Age thought. In Germany, this skepticism is fueled by Bernhard Maier's recent book on Germanic Religion (Maier, Die Religion der Germanen), which is widely read in Asatru circles and summarizes the problems of this concept.

31 "Die Diskussion erübrigt sich meines Erachtens für den praktischen Bereich, denn selbst wenn mir jetzt $\mathrm{x}$ Wissenschaftler belegen, daß die innige Beziehung zu einem/r Gott/ 
This, however, implies that the ideological dimensions of the concept of the fulltrúi are rarely discussed.

It comes as no surprise that the deities to whom Asatruers relate most frequently are the ones best known from mythology and its various popularizations throughout the centuries, i.e. Odin/Wotan, with Thor $^{32}$ being a close runner-up; the love and fertility goddess Freya and her counterpart Freyr; Odin's wife Frigg; and Tyr, who is perceived as a god of justice. ${ }^{33}$ In German and Anglo-American Asatru, another goddess, Ostara, ranks highly as well. This goddess' surmised existence goes back to a misunderstanding by Jacob Grimm and became immensely popular in Romanticism. ${ }^{34}$ She appeals to contemporary Anglo-Saxon and German Heathens to the degree that they abandon their claims of scholarly-based authenticity and worship this spring goddess around Easter, because it "works for them."35

The only controversial case when it comes to the worship of deities in Asatru is that of Loki, the troublemaker and trickster of the Nordic pantheon. Racial-religious Asatruers see him as the spawn of miscegenation (he is the child of a god and a giant); others view him as a destructive force due to his role in the killing of Balder and the demise of the gods in Ragnarok. A few, however, especially those who are interested in 'shamanistic' practices or seid, or in questions of gender and the transgression of gender boundaries, see him as a problematic although interesting figure, who deserves attention and careful worship. ${ }^{36}$ In addition to these deities, entities from

Göttin originär christlich sei, weiß ich doch, was ich erfahren und gefühlt habe. Und das zählt doch wohl." Thread "Fulltrui - was sagen die Quellen?" (http://www.eldaring.de/ pages/forum---community.php, last accessed November 27, 2012).

32 Jóhanna Harðardóttir in Iceland claimed that Thor is (and has been through the ages) most Icelanders' favorite deity, whereas mainland Scandinavians tend to adhere to Odin, cf. Interview with Jóhanna Harðardóttir (Ásatrúarfélagið), August 12, 2010, Iceland.

33 The quantitative evaluation of Gründer's interviews shows a similar tendency with mentions of Odin leading, followed by Thor (127), Freyja (80) and Loki (72), see Gründer, Blótgemeinschaften, 248.

34 Ostara's worship is related to a passage in Jacob Grimm's German Mythology, based on his reading of Bede's account. In Ecclesiastical History of the English People (around $731 \mathrm{AD}$ ), the Anglo-Saxon monk writes about a Germanic spring goddess, Eostrae, from which the term Easter (German Ostern) is supposedly derived.

35 See for example MartinM, "Ostara - oder: dem Fest ist es egal, ob eine Göttin so heißt," Nornirs Ætt, http://www.nornirsaett.de/ostara-oder-dem-fest-ist-es-egal-ob-eine-gottinso-heist/, last accessed June 03, 2015.

36 See for example Interview L. For a general discussion of Loki's contested nature in Asatru see Diana L. Paxson, Essential Asatrú. Walking the Path of Norse Paganism (New York: Citadel Press, 2006), 72. 
'low mythology,' e.g. local spirits of nature called væettir, play a role. ${ }^{37}$ This emphasis on beings known not only from written mythological sources but also from folk religion and customs seems to be an increasing trend in Asatru today.

Relations and interactions between humans, gods, and other (super)natural entities such as the aforementioned vettir, dwarves, giants, elves, etc. are theorized more or less elaborately in different countries and groups. Most Heathens refer to Eddic sources regarding Yggdrasil, the World Ash Tree that encompasses the nine worlds ('níu heimar') in which the different species of beings reside. Neither scholars nor Heathen practitioners agree about the nature and significance of these 'worlds' and their respective inhabitants. ${ }^{38}$ A number of elaborate theories have been put forth which are particularly influential within Anglo-American Asatru. Every basic discussion by Heathens about their faith, or by outside researchers, will give at least a summarizing account of the location and meaning of the nine-world model. Frequently, the nine worlds are described as levels of individual and cosmic consciousness, ${ }^{39}$ a concept which was initially developed by Edred Thorsson in A Book of Troth. ${ }^{40}$ This concept opens up a variety of esoteric speculations about correspondences between the nine worlds, the runes, and astrological signs, etc. ${ }^{41}$

The idea of the nine worlds corresponds with the postulation of different types or aspects of human 'souls,' or physical, psychic, and spiritual levels of existence. Frequently, this model is used to distinguish Asatru's understanding of an intricate psychosomatic wholeness from the Christian tradition's supposedly simple dichotomic split between body and soul, matter and

37 For Danish Asatru author Gudrun Victoria Gotved, Asatro. De gamle guder i moderne tid (Copenhagen: Aschehoug, 2001), 30, the gods are "not for daily use."

38 For a scholarly discussion, see for example Margaret Clunies Ross, Prolonged Echoes. Old Norse Myths in Medieval Northern Society: The Myths, vol. 7, The Viking Collection, Studies in Northern Civilization (Odense: Odense University Press, 1994), 50-56, who incidentally does not work with a neat system of nine worlds, but alerts to the complex and contradictory spatial structures in eddic literature.

39 Cf. Pete Jennings, The Norse Tradition. A Beginner's Guide (London: Hodder \& Stoughton, 1998), 26f, as well as the summary in Harvey, Listening People, Speaking Earth, 54.

40 Edred, A Book of Troth. Runa-Raven Yrmin-Edition (Smithville, Tx: Runa-Raven Press, 2003), 22.

41 See e.g. GardenStone, Germanische Magie (Engerda: Arun, 2001), 75-77. Such principles of esoteric correspondences between micro- and macro-cosmos are frequent in other groups as well. See Brochure "Åsatrofellesskapet Bifrost," ed. Åsatrufellesskapet Bifrost (2002), 9 . 
spirit. ${ }^{42}$ These elaborations also seem to be limited to the wider context of the American Troth and groups influenced by it or by Edred Thorsson's and Kveldulf Gundarsson's writings. The connection of concepts of souls with various forms of rebirth in the kin or clan, ${ }^{43}$ or with reincarnation in general, ${ }^{44}$ has traditionally been more widespread. ${ }^{45}$ Today, most Asatru groups do not make official statements about this issue, but instead leave it up to the individual members.

The concept of the World Tree in Norse mythology in general, as well as Asatru in particular, is tied to the mythological figures of the three norns, Urd, Verdandi, and Skuld, who, according to Eddic accounts, reside at the Urd Well at the roots of Yggdrasil. These figures, which have often been compared to the Moirae or Parcae (the Fates of Greek and Roman antiquity), give cause to much speculation and theorization about the role of fate or wyrd in Heathenism and the existence of an alleged characteristic 'Germanic fatalism' (Germanischer Schicksalsglaube). ${ }^{46}$ Although the book Our Troth claims that "there are not contradictions [with our religion] as there are in other faiths," ${ }^{27}$ many Heathens agree with Graham Harvey's assessment of there being "an ambivalence or oscillation between fatalism and free-will" 48 within Asatru. This ambivalence is illustrated in the following reflections by a Norwegian Asatruer:

Actually, it is impossible to prove how far there is a fate or a free will. It depends on one's perspective. [...] Shall we believe in both responsibility

42 Cf. "Germanischer Seelenglaube und Seelenkonzepte im modernen Seidhr" (http://eldaring.domainfactory-kunde.de/ELDARING_4/board58-artikel-germanisches-heidentum/ board62-runen-und-magie/7750-germanischer-seelenglaube/, last accessed September 16, 2014). Cf. also Gundarsson, Our Troth, vol. I, 499-508.

43 See ibid., 508.

44 Gotved, Asatro. De gamle guder i moderne tid, 39.

45 The German Armanen-Orden, as well as the Icelandic Nýalssinna, held the belief that souls undergo various incarnations in different 'lower' and 'higher' races, in order to develop and finally incarnate on other, more highly developed planets. Cf. Schnurbein, Religion als Kulturkritik, 5 of, and 177-179.

46 In particular, the etymological proximity of 'urd' to the Anglo-Saxon term 'wyrd' (which is again echoed in the modern 'weird'; Shakespeare's "weird sisters" on their part being an echo of the three fates) has motivated most of the prominent English and American Asatru authors to consider the available research on 'wyrd' and reflect about the role of fate.

47 Gundarsson, Our Troth, vol. I, 523.

48 Harvey, Listening People, Speaking Earth, 56. Gründer, Blótgemeinschaften, 210, comes to a similar conclusion and observes that worldviews of Asatruers are deterministic to varying degrees. 
for our own actions and fate? Perhaps, it's difficult to balance. That's the stuff we modern Heathens struggle with. ${ }^{49}$

Authors writing about wyrd agree that it is not an immutable, divinely imposed 'fate,' but rather the expression of an interaction between past deeds and their consequences in the present which form the future. This results in a complicated web of cause and consequence, to which all beings, including the gods, are subject. Such a worldview also gives rise to reflections about the significance of past, present and future. Based on the observation that Germanic languages do not have a separate form for future tense, but instead need an auxiliary verb such as 'will' or 'shall' to express it, the conclusion is drawn that the rootedness of the 'folk' in the past takes on an a remarkable significance. This idea can be traced back to Romanticism, and is expressed emphatically in this passage from Our Troth:

To us, that-which-is, 'the past,' is not gone or lost: it is forever living and green, and more, it is the source from which all springs, even as the roots are the source of the tree. New branches can spring forth if the crown is chopped off; but the destruction of the roots is the end: and thus it is with our folk. To lose the ways of our forebears - to lose our foothold in thatwhich-is, or get too far from their thoughts and beliefs - is to be rootless trees and to die. ${ }^{50}$

This notion of rootedness in the past is often set against either a "Mediterranean" or a Christian perception of a "linear past, present, and future,"51 which by some is seen as potentially dangerous to the invoked "roots" of Germanic faith. ${ }^{52}$ Such reflections on the significance of roots and ancestors also show how easily ethnic arguments enter into the worldview of a-racist Asatruers.

Concepts of wyrd (skcebne, or Schicksal, the terms for 'fate' in Danish and German) are most elaborated in Danish, German, and especially AngloAmerican Asatru. This is related to two factors. Firstly, the concept of wyrd has

49 "Hvorvidt det fins en skjebne eller om man har fri vilje, det er umulig å bevise, egentlig. Det kommer an på perspektivet man har. [...] Skal man kunne tro på både ansvar for egne handlinger og skjebne? Kanskje vanskelig å få til å gå opp. Det er sånt som vi moderne hedninger strir med." Interview $\mathrm{O}$.

5o Gundarsson, Our Troth, vol. I, 487 f.

$5^{1} \quad$ Teutonic Religion. Folk Beliefs \& Practices of the Northern Tradition, 15.

$5^{2}$ Such dichotomies are discussed in detail in Chapter 5 . 
enjoyed a strong interest within Anglo-Saxon scholarship. ${ }^{53}$ Secondly, the popularity of the topic of fate in a broader sense has to do with the attention one particular book has attracted in Danish, German and Anglo-American Heathen communities, the Danish historian of religion Vilhelm Grønbech's The Culture of the Teutons (1909-1912). His imaginative summary of the mentality and worldview of "our ancestors" 54 elaborates the concepts of orlög (another word for fate), hamingja (referring to the 'luck' of a clan or kinship group), and frith (an active form for peace within the group, when its hamingja is present). The frequency of the use of these Grønbechian key terms is a good indicator for his influence in different contexts. ${ }^{55}$

For everyday ethics, only certain aspects of wyrd or fate are foregrounded. With few exceptions, Heathens agree that good and evil are categories imposed by Christianity, and thus apply to Heathen ethic as little as the ideas of sin, punishment, redemption, and judgement. They are replaced by the allegedly Heathen idea that one's deeds are all that count, which influences the web of wyrd, and bears consequences for which each individual is responsible. Many Asatruers mention this idea of personal responsibility for one's own actions and a principle of 'honor' as the most appealing aspects of their religion, appreciating it primarily because of its simplicity and straightforwardness. In Iceland, this attitude was codified already in 1972, in the second article of Ásatrúarfélagið's rules: “The main core of this custom [sið] is the responsibility for oneself and one's actions. In this matter we make use of the Snorra-Edda and other holy scriptures." 56

A female member of the Norwegian Bifrost put it this way:

53 The most influential work in Asatru contexts is no doubt Paul Bauschatz' The Well and the Tree, a thorough investigation into the World and Time in Early Germanic Culture (Paul Bauschatz, The Well and the Tree. World and Time in Early Germanic Culture (Amherst: University of Massachusetts Press, 1982)). Around the same time, the idea was popularized in Neopagan spiritual contexts, e.g. by psychologist Brian Bates, "professor of shamanic consciousness at the University of Brighton" in his fictional account of the spiritual experiences of an "Anglo-Saxon Sorcerer" (dust cover for Brian Bates, The Way of Wyrd. Tales of an Anglo-Saxon Sorcerer, 2. ed. (Carlsbad, cA: Hay House, 2005 [1983])).

54 Vilhelm Grønbech, Vor Folkexet i Oldtiden, 4 vols. (Copenhagen: Pìos, 1909-12). English edition The Culture of the Teutons, 2 vols. (London: Oxford University Press, 1931).

55 For a discussion of Grønbech's significance and a critique of such approaches see Chapter 8.

56 "Helzta inntak pessa siðar er ábyrgð einstaklingsins á sjálfum sér og gerðum sinum. Í pessu efni hófum við hliðsjón af Snorra-Eddu og öðrum helgiritum." Quoted from Jonsson, "Ásatrú á Íslandi við upphaf 21. aldar," 98. 
If you make a wrong choice, then you have to deal with the consequences right away, and then it is not God who is angry at you, it is just you who has made a wrong choice, and then you have to learn from it, and then you don't do it another time, right? ${ }^{57}$

The particular interpretations of concepts such as responsibility and honor range from everyday ideas about being "able to look at myself in the mirror in the morning" 58 to calls for a vitalist warrior heroism. An article in the German journal Herdfeuer takes up the main themes of such a Germanic amor fati:

To live in the North has always meant to bend to the unavoidable, to make use of the opportunities that offered themselves, and to do what needed to be done as thoroughly as possible. What the nature of the North taught our ancestors, we find in their myths. Fate appears as inexorable as the invading winter. Everything that happens is interwoven, often in a fatal way. One deed leads to the next; everything comes as it has to come. Man is left to do what has to be done. [...] But astonishingly enough, in this world where everything is counted and weighed, we find not a trace of a rebellion against unjust fate, no disappointed turning away from the brutal world. Neither was there a cynical nihilism, no withdrawal into satisfying private appetites as one might expect. The characters who meet us in Germanic mythology fulfilled their fate with verve, they were full of life-energy, active, self-confident. Not that they resigned to their fate, no, they seemed to positively love their fate. [...] A true lifefervor inhabited these people. They were animated by a fighting spirit. Life was sacred to them, and fate, the wyrd, that what has become as it is called in Germanic tradition, was life, being, in and of itself. It was given to man at his birth, and he took part in it all his life, was rooted as an individual in the eternal deep ground of being. He knew that something sacred lived in him - that force which gives life to his heart and his loins. This made him worthy of life and his life worthy of living. This was the basis of his courage and his honor. ${ }^{59}$

57 “Gjør du et feil valg, så må du ta konsekvensen av det med én gang, og da er det ikke Gud som er vred på deg, det er bare du som har tatt et feil valg, og så må du lære av det, og så gjør du ikke det samme neste gang, ikke sant?" Interview P.

58 Ibid.

59 "Im Norden zu leben hat immer geheissen (sic), sich dem Unvermeidlichen zu beugen, die Chancen zu nutzen, die sich boten, und das, was zu tun war, möglichst gründlich zu tun. Was die Natur des Nordens unseren (sic) Vorfahren gelehrt hatte, finden wir in ihren 
This quote, describing a Germanic Heathen fatalism, foregrounds an activist religion of 'deed' which favors heroism in the face of natural hardships and places values such as honor in a position of preeminence. It can be read as a 21st century reflection of the popular Nietzscheanism which permeated early 2oth century intellectual culture in Germany and elsewhere in Europe ${ }^{60}$ and which informed the belief in the absolute value of actions of atonement: the Tat, action, or deed in Germanic Faith as well. In the first part of the 2oth century, GGG-founder Ludwig Fahrenkrog summarized it emphatically in the slogan "God in us - the law in us - 'the self-redemption"'61 and explained:

Action became action and lives on in its consequences, and action was mine eternally. Nothing eradicates it, nobody else's action, but the healing, bettering action done by myself - the action that makes any wrong right again or - atones for it. ${ }^{62}$

Mythen. Unerbittlich wie der einfallende Winter erscheint uns hier das Schicksal. Alles, was geschieht, ist, oft auf verhängnissvolle (sic) Weise miteinander verwoben. Eine Tat führt zur anderen, alles kommt, wie es kommen muss. Dem Menschen bleibt, zu tun, was zu tun ist. [...] Doch erstaunlicherweise finden wir in dieser Welt, in der alles gezählt und gewogen ist, keine Spur einer Revolte gegen das ungerechte Schicksal, keine enttäuschte Abkehr von der brutalen Welt. Es gab auch keinen zynischen Nihilismus, keine Rückzug in die Befriedigung privater Gelüste, wie man vermuten könnte. Die Figuren, die uns in der germanischen Mythologie entgegentreten, erfüllten ihr Schicksal mit Verve, sie waren voller Lebensenergie, aktiv, selbstbewusst. Nicht, dass sie sich in ihr Los schickten, nein, sie schienen ihr Schicksal förmlich zu lieben. [...] Eine wahre Lebenswut wohnte diesen Menschen inne. Sie waren vom Kampfgeist beseelt. Das Leben war ihnen heilig, und das Schicksal, das 'Gewordene,' wie es in germanischer Tradition so treffend heißt, war das Leben, das Sein, an und für sich. Es wurde dem Menschen mit seiner Geburt gegeben, und er hatte ein Leben lang daran Teil, wurzelte als Individuum im ewigen Urgrund des Seins. Er wusste, dass in ihm etwas Heiliges lebte, jene Kraft, die sein Herz und seine Lenden belebte. Dies machte ihn würdig zu Leben und sein Leben lebenswürdig. Dies war die Grundlage seines Mutes und seiner Ehre." Peter Walthard, "Die alte Sitte," Herdfeuer 2, no. 3 (2004), 5 .

6o For an in-depth discussion of the widely varied appropriations of Nietzsche's thought in Germany see Steven E. Aschheim, The Nietzsche Legacy in Germany 1890-1990 (Berkeley: University of California Press, 1992).

61 "Gott in uns - das Gesetz in uns - 'die Selbsterlösung." Quoted from Junker, Gott in uns!, 39 .

62 Fahrenkrog 1923: "Die Tat ward Tat und lebt in ihren Folgen fort, und immerdar war mein die Tat. Nichts tilgt sie, keines anderen Tat, als nur die heilende, bessernde Tat von mir getan - die Tat, die jenes Unrecht wieder recht macht oder - sühnt." 
Such notions are taken up by Theodist Eric Wodening, an early member of the Ring of Troth, who gave his frequently cited book the telling title We Are Our Deeds ${ }^{63}$ - an almost literal quotation of Ludwig Fahrenkrog's famous motto for the Germanische Glaubensgemeinschaft: "Deine Tat bist du!" (You are your deed!) Generally speaking, we can note a transformation of the ideals of honor, deed, and self-redemption in Germanic Neopaganism from a racial-biological, Social Darwinist framework in the 1920 s to 1940 os to an individualized concept, no longer tied to a people, nation, or race. René Gründer aptly calls this process "traditionalizing individualism." ${ }^{4}$ Such individualism (including its masculinist, heroicist overtones) seems indeed adaptable to a late modern agenda. However, we should not overlook the fact that völkisch religion and German Faith in the early 2oth century was also not exclusively dependent on a biological paradigm. The aforementioned religious models also owed much to liberal theology and to liberal and Nietzschean critiques of religion. The quotes also show that remnants of Social Darwinism are still active within parts of Asatru today. ${ }^{65}$

German a-racist Nornirs $A t t$ is the only group that I encountered which harks back to the concept of wyrd, yet squarely opposes any cult of heroism and the explicit or implicit disdain for weakness. Instead, the small group stresses the importance of a community based not only on consensus but also on the principle of consideration for its weakest members. One of the early members wrote the following explanatory sentences:

Nothing has impressed me more from the beginning than the consistent strategy of our initial spokespeople to abolish their own status. [...] Nornirs Ett is a community in which you may show weakness without provoking strength. THAT is OUR strength: We are a home for handicapped people - nothing but totally normal people who have one [...] guarantee - that our speed is determined by those who walk slowest. THAT is what WE call (with some hubris, I know) 'Germanic.'66

63 Eric Wodening, We Are Our Deeds.The Elder Heathenry. Its Ethic and Thew (Watertown, NY: Theod, 1998).

64 Gründer, Blótgemeinschaften, 273, cf. his discussion of Heil and hamingja, 272-275.

65 The example of Anthony Winterbourne, When the Norns Have Spoken. Time and Fate in Germanic Paganism (Madison/Teaneck: Fairleigh Dickinson University Press, 2004), shows that the idea of an "all-embracing fate" that "somehow leaves room for pride, dignity, and defiance, rather than an encouragement to supine submissiveness" is interesting for popular philosophy about fate, time, heroism, and action as well.

66 "Denn kaum etwas hat mich von Anbeginn an mehr beeindruckt als die konsequente Strategie unserer anfänglichen Wortführer, ihren eigenen Status abzuschaffen. [...] 
Most of these contradictions and implications remain latent though. Asatruers tend to appreciate the relative simplicity and straightforwardness of their ethic of responsibility, and very few intervene critically. A rare voice of concern by a "Heathen academic in the us" is quoted by Jenny Blain:

Seeing all the 'trailer park philosophies' being peddled, a horrible thought occurred to me: Maybe one of the reasons Asatru is appealing to some folk is because the ethical codex laid out in the Havamal is very 'motherhood and apple pie.'... If you strip away all the mythological veneer and 'far away Iceland in a different age' type mystique, all that remains from the Havamal is a behavioural codex that is about as complex as Fulghum's 'All I needed to know I learned in Kindergarten.'67

The idea that Germanic Neopaganism is based on a worldly ethic of action and not on a belief in supernatural beings fueled the debate as to whether Asatru should be considered a religious belief system, or rather a philosophical worldview and cultural tradition based on practices that should be preserved, revived, and transformed. ${ }^{68}$ The latter position, as well as the claim that in Heathenism "religious and social community are identical,"69 is gaining ever more prominence within Asatru. This has led a number of groups to reject the term 'Asatru' and replace it with terms like 'Forn Sed' or 'Alte Sitte,' meaning

Die Nornirs Ætt ist eine Gemeinschaft, innerhalb derer du dich schwach zeigen darfst, ohne Stärke zu provozieren. DAS aber ist UNSERE Stärke: Wir sind Heimat für Behinderte - lauter stinknormale Menschen, die eine [...] Garantie haben. Nämlich die, dass unser Tempo bestimmt wird von denen, die am langsamsten laufen. DAS nennen WIR (mit einiger Hybris: I know) 'germanisch." Correspondence with Duke Meyer.

67 Blain and Wallis, "Heathenry," 242. One might add the question in how far the cautionary and skeptical advice of the Hávamál, a poem originating in a society ruled by an oligarchy and split by violent feuds, can and should be adapted to contemporary conditions at all.

68 This question already led to controversies and schisms between Ariosophy and German Faith, cf. Gründer, Blótgemeinschaften, 166, as well as Junker, Gott in uns!. However, there have neither been clear borders between the two camps, nor is it possible to say that one of the sides is per se closer to a racial-religious paradigm. Esoteric speculation today can be found both in ariosophic and a-racist groups while a cultivation of tradition is practiced in racial-religious organizations such as the Artgemeinschaft in Germany as well as in culturally (but not necessarily politically) conservative groups such as Foreningen Forn Sed in Norway.

69 "Religiöser und sozialer Verband [sind] identisch." Asfrid, "Heidnische Grundbegriffe," Ringhorn. Gemeinschaftsanzeiger des Vereins für germanisches Heidentum e.V. $5^{1}$ (2007), 11. 
'the old way,' 'the old tradition,' or 'custom.' In doing so, they acknowledge that pre-Christian Scandinavians or Germans did not have a name for their religion, and that the term 'Asatru' is an invention of Scandinavian National Romanticism. They see the emphasis on 'tru' (belief, or faith) as an ultimately Christian notion, which does not reflect the activist and practical nature of modern (and in their eyes also ancient) Heathenism. This increasingly common attitude explains why there is room for so many divergent ideas about deities and other supernatural beings and their relations to humans and the world. Moreover, it places ritual practices at the center of contemporary Germanic Neopaganism, as Fritz Steinbock, of the German VfgH, writes:

Rituals are the traditional core of Heathenism. It is not a dogmatic religion that places the belief in its teachings in the center, but a living relationship to the gods, to nature and to everything holy that realizes itself actively. It is not theory, but practice. Being a Heathen means to practice Heathenism. ${ }^{70}$

\section{Heathen Practices}

The above quote is representative of another typical feature within current Asatru. Ritual is seen as an aspect of religion connected to a lived reality and sense of authenticity. There is no general critique of ritual (for example as a stifled, petrified, and oppressive social force) although many Asatruers reject 'dogmatism' with regard to beliefs. I have found no instance where this implicit contradiction is addressed, and many Heathens today indeed agree with Steinbock's assertion that ritual is at the center of, and defining for, their religion. ${ }^{71}$ Most groups use the term 'blot' (often spelled blót) for their main ritual activity. ${ }^{72}$ There is extensive agreement that the purpose of the blot is to connect with the deities, to communicate with 'the powers', and, at least in case of communal blots, to strengthen the human community and group coherence.

70 "Rituale sind das traditionelle Herzstück des Heidentums. Es ist keine dogmatische Religion, die den Glauben an ihre Lehren in den Mittelpunkt stellt, sondern eine lebendige Beziehung zu den Göttern, der Natur und allem Heiligen, das sich tätig verwirklicht. Es ist nicht Theorie, sondern Praxis. Heide sein heißt das Heidentum auszuüben." Fritz Steinbock, Das heilige Fest. Rituale des traditionellen germanischen Heidentums in heutiger Zeit, 2. ed. (Hamburg: Verlag Daniel Junker, 2008), 13.

71 See also Interview $\mathrm{O}$.

72 The term is derived from the Icelandic sagas. 
Also in this respect there has been a fluctuation over time. From the 1920 so the 1940s, the communal aspect was predominant, while the 1970s and 8os saw an increasing individualization of rituals. Today, there seems to be a shift back to the emphasis on community celebrations.

In his discussion of Icelandic Asatru, Eggert Solberg Jonsson roughly distinguishes four types of ritual which can be also applied to most modern Asatru groups in other countries: Rituals of the solar cycle, rituals for other occasions (including different types of Heathen historical memorial days), individual rituals of the life cycle, and individual solitary or communal rituals to connect with deities and ask for help or advice. ${ }^{73}$

The basic structures of communal blots in most groups are similar, and usually comprise the following elements:

1. The delineation of a ritual space, usually a circle of the participants around a fire or another sacral center (an altar, statues or images of deities, symbolic objects). This is frequently done by invoking the four points of the compass.

2. The invocation of gods and goddesses.

3. The passing of a horn filled with mead or another, usually alcoholic, drink to all participants, who then drink to the gods, making wishes or boasts.

4. A donation of food, or sometimes objects.

5. The opening of the circle.

This is frequently followed by a communal meal, which in some groups forms the actual ritual itself. ${ }^{74}$ The common general structure for the blot varies according to the ideals of the group or the requirements of the occasion. Some, such as the $\mathrm{VfgH}$, include the incantation of runes. The outspokenly anti-racist Swedish Samfundet Forn Sed starts its blots by raising a so-called nid, a type of banishment or spell against groups who they feel misuse Asatru for political or racist purposes. ${ }^{75}$ Danish Forn Siðr has incorporated readings of Eddic texts into their official ritual.

73 Jonsson, “Ásatrú á Íslandi við upphaf 21. aldar," 159 f.

74 English and American groups, as well as the German Eldaring that grew out of the American Troth, call the latter, i.e. a ritual exclusively devoted to the passing of the horn, praising the gods, making toasts and boasts, a 'Sumbel.' For a more detailed discussion of different tendencies in the ritual practices of German Asatru see Gründer, Blótgemeinschaften, 108-112.

75 Cf. Gregorius, Modern Asatro, 230. The practice of raising a "Nidstang," a pole of banishment, refers to an event described in the Egilssaga where a horse's head was raised on a pole in order to ward off an enemy. 
There is also a somewhat general agreement about the times for the main blots. In most groups, they are held at or around the solstices and equinoxes. ${ }^{76}$ Scandinavian and German groups today hold most of their rituals outdoors, a practice that they perceive to be most authentic. Some groups and individuals choose to hold blots at locations that are considered preChristian sites of worship. Swedish and Icelandic Asatru groups have succeeded in establishing their own national traditions of annual worship at sites considered national treasures. Ásatrúarfélagið celebrates once a year at Thingvellir, the site (today a national park) where the medieval Icelandic legislative and judicial assembly, the Althingi, was held between 930 and 1271. Since 2000, Swedish Asatruers have had permission to celebrate a blot at Gamla Uppsala (Old Uppsala), a site of Iron-Age burial mounds considered a pre-Christian center of administration and worship, which later became Sweden's archbishopric. ${ }^{77}$ Both events attract considerable media attention, and are seen as important symbolic events positing Asatru in overt competition with the dominant Christian churches. Both Gamla Uppsala and Thingvellir were used, by Swedish and Icelandic Asatruers respectively, in the year 2000 to mark a reclaiming of traditional Heathen sites - acts which led to some controversy as well as welcome media attention for Asatru groups. ${ }^{78}$ In Germany, the Externsteine, near the Teutoburg Forest, as well as the Sachsenhain, the alleged site of the killing of Saxon leaders by Charlemagne in the 8th century, have served similar functions. However, both are strongly contested sites and are today only wholeheartedly embraced by racial-religious

76 The Icelandic Ásatrúarfélagið celebrates the spring and fall blots at slightly different times in mid-April and mid-October, basing these dates on mentions of different celebrations in medieval Icelandic sagas and Eddic literature. Individual Godis have also established their own traditions of annual blots at different times of the year, cf. Jonsson, "Ásatrú á Íslandi við upphaf 21. aldar," 170-173. Some groups additionally celebrate at other times of the year as well, Easter (Ostara) being popular amongst German groups. Thorrablót, a festival mentioned in some medieval Icelandic sources which marks the last month of winter (Thorri), was re-created by Icelandic students in the late 19th century in the tradition of contemporary student fraternities' drinking rituals. It has become widely popular in Iceland in general, amongst the Ásatrúarfélagið, and other Scandinavian groups as well, cf. ibid., 75, 196.

77 For information on the contemporary museum at Gamla Uppsala see http://www.raa.se/ cms/extern/se_och_besoka/gamla_uppsala.html, last accessed March 29, 2014.

78 The Icelandic case is discussed in Strmiska and Sigurvinsson, "Asatru: Nordic Paganism in Iceland and America." For Sveriges Asatrosamfund's celebrations in Gamla Uppsala see Gregorius, Modern Asatro, 103. 
groups due to their extensive use by National Socialism, which tried to establish them as German national sacred sites. ${ }^{79}$

The question of proper locations for local, regional and national celebrations is tied closely to debates about the extent to which it is important or appropriate for Asatru to establish temples or halls of worship. Some American groups, as well as the Icelandic Ásatrúarfélagið, attempt to build their own halls of worship, often called Hof. Others, such as Asatrofcellesskabet Yggdrasil and Nordisk Tingsfeellig in Denmark, or the Olgar Trust in England, aim at purchasing land to dedicate to Heathen celebrations. ${ }^{80}$ The lack of funds, and the attitude that official temples are not appropriate for a 'nature religion,' caused considerable controversy between different Germanic Faith groups in the 1920s. Ambitious plans to construct such sites of worship, such as those of Ludwig Fahrenkrog and Fidus, were never realized, however. ${ }^{81}$ The establishment of temples is a minor issue in current Asatru as well. ${ }^{82}$

In addition to seasonal festivals, Asatruers observe events in the life cycle, such as the birth or naming of a child, coming of age, marriage, and death. For Scandinavian groups, which are or were functioning within state church systems, it became particularly important to be able to officially conduct marriages as well as funerals. Norwegian, Danish and Icelandic groups have attained this right with their official recognition by their respective states, and by now also have their own funeral sites. These aspects are of less importance in countries like Germany and the Netherlands, where official marriages may only be conducted by state authorities, whereas all

79 For the Externsteine see Volker Schockenhoff, “Stonehenge' contra 'Störrische Kuh," in Wir zeigen Profil. Aus den Sammlungen des Staatsarchivs Detmold. Ausstellung des Nordrhein-Westfälischen Staatsarchivs Detmold (Detmold: NW Staatsarchiv, 1990) and Uta Halle, 'Treibereien wie in der NS-Zeit.' Kontinuitäten des Externsteine-Mythos nach 1945," in Völkisch und national. Zur Aktualität alter Denkmuster im 21.Jahrhundert, ed. Uwe Puschner and G. Ulrich Großmann (Darmstadt: WBG, 2009), for a discussion of the Sachsenhain as a National Socialist and German Faith site of worship see Justus H. Ulbricht, “'Heil Dir, Wittekinds Stamm.' Verden, der "Sachsenhain” und die Geschichte völkischer Religiosität in Deutschland, Teil 1 und 2," in Heimatkalender für den Landkreis Verden: Verdener Sachsenhain, Jahrbuch 1995 und 1996, ed. Landkreis Verden (Verden: Landkreis Verden, 1995/96).

8o For a discussion of this strategy, see Chapter 6.

81 Cf. Rainer Y, Fidus, der Tempelkünstler. Interpretation im kunsthistorischen Zusammenhang mit Katalog der utopischen Architekturentwürfe, 2 vols. (Göppingen: Kümmerle, 1985).

82 For such debates on temple building in Germanic Neopaganism see also Chapters 1 and 9. 
religious ceremonies - including Christian ceremonies - are regarded as personal matters. ${ }^{83}$

It is not easy to determine the exact origins of the modern Asatru practice of blot. The first groups to apply the term were the Icelandic Ásatrúarfélagið, the British Odinic Rite, and the $A F A .{ }^{84}$ The international spread of ideas on the blot can probably be attributed to Edred Thorsson's books, (e.g., A Book of Troth) and later Kveldulf Gundarsson's writings. Concurrently with the Odinic Rite and the Ásatrúarfélagið, the German Armanen-Orden (especially Sigrun von Schlichting) developed their own rituals. ${ }^{85}$

Since medieval sources are notoriously quiet about Heathen practices, elements of rites can rarely be traced back to or even considered to have been inspired by them. The few accounts of rituals found in medieval saga literature mention a temple (hof) where statues of gods are erected and sprayed with the blood of sacrificed animals. ${ }^{86}$ The question is rarely asked how authentic these descriptions are, or to what extent they are creative imaginations by Christian minds fantasizing about the 'bloody' and 'primitive' practices of Heathens. ${ }^{87}$ Be that as it may, the mentioned practices are not part of modern Asatru rituals. ${ }^{88}$ The only aspect from medieval sources that is included in contemporary blots is the ritual drinking and toasting. This is probably a reflection of a 19th century Romantic imagination of medieval drinking rituals, which also found expression in student fraternities. ${ }^{89}$

83 In Germany, a burial site for non-denominational as well as völkisch religious individuals was erected in 1958 in Conneforde, cf. Gründer, Blótgemeinschaften, 116.

84 The Odinic Rite started early on to codify the rituals its members designed into the Book of Blotar (cf., Stubba, The Book of Blots. Ceremonies, Rituals \& Invocations of the Odinic Rite (London: Odinic Rite, 1991)), whereas the $A F A$ 's rituals were documented by Stephen McNallen in three booklets Rituals of Ásatrú in 1985, the first carrying the sub-title Major blots (cf. Stephen A. McNallen, Rituals of Ásatrú. I Major Blots (Breckenridge, Tx: The Ásatrú Free Assembly, 1985)).

85 Cf. Schnurbein, Religion als Kulturkritik, ${ }_{56-61}$, Gründer, Blótgemeinschaften, 169.

86 Cf. Martin P. Hansen, "Blótets liturgi, før og nu," Vølse 45 (2008).

87 See for example Rudolf Simek, Religion und Mythologie der Germanen (Darmstadt: WBG, 2003), 282.

88 A few Asatruers mentioned that they use animal blood bought from butchers in their private rituals. The only exception I could find is High Theodism, which allegedly practices animal sacrifices conducted by members trained in proper butchering. See Lord, The Way of the Heathen, 23 .

89 For a reception of such rituals in circles of Icelandic students in Copenhagen in the late 19th century as well as in 19th century National Romantic Icelandic paintings, plays etc. that make use of the motives of drinking to the dead, the ancestors, and the gods, see Jonsson, "Ásatrú á Íslandi við upphaf 21. aldar" 75-82. 
At the same time, there are a number of similarities between Asatru rituals and Wiccan practices: outdoor worship, the circle, the hallowing of the four directions, and the dates for the four main seasonal celebrations. ${ }^{90}$ These unquestionable parallels have a number of possible explanations. On the one hand, Wicca is, as mentioned, the largest and most influential faction within modern Paganism, and has thus formed popular ideas about the general nature of Pagan religions. ${ }^{91}$ In Asatru, connections to Wicca are frequently despised, denied, or downplayed, either because Wicca is perceived as being too libertarian, permissive, and leftist (this is often the case in North American Asatru), or because it is seen as a fictional religion which rivals the establishment of a 'real,' authentic, indigenous Paganism (as many European, particularly Scandinavian Asatruers claim). In spite of this, many Asatruers have been involved with Wicca, making mutual inspiration likely. This is also true for some of those Asatruers who set out to construct rituals in the 1980s and gos and dispersed them throughout the Asatru world. ${ }^{92}$

On the other hand, not all of the Wiccan-looking elements necessarily have to be attributed to a direct influence of Wicca on Asatru. Rather, some may also

9o In addition to the equinoxes and solstices, which are celebrated in Asatru as well as in Wicca, Wicca has four seasonal celebrations between these dates. In some Asatru groups, an equivalent to these is also celebrated.

91 For an in-depth discussion of Wicca's success in creating a functional new religion and forming perceptions about Paganism in general see Hutton, The Triumph of the Moon.

92 This applies to Freya Aswynn (http://www.aswynn.com/about-me.html, last accessed March 19, 2014) and Prudence Priest (AFA, American Vinland Association) who is an elder in the Wiccan Covenant of the Goddess (cf. Sylvana SilverWitch, "Just 'Wiccatru' Folk. A Word With Prudence Priest," Widdershins, http://www.widdershins.org/vol_iss6/y9702. htm, last accessed November 01, 2011). Theodism started as an split-off from Wicca. The founder and leader of the Yggdrasil Kreis, Volkert Volkmann, holds amongst other things, a Wicca Master Degree (cf. http://www.yggdrasil-kreis.org/html/runasongr.html, last accessed March 19, 2014). It should be mentioned that the Odinic Rite is one of the groups that most vehemently rejects Wicca. Nevertheless, Volkert Volkmann was a professed member of the $O R$ as well. According to former $V f g H$ leader Haimo Grebenstein, the collaboration with the Yggdrasil Kreis in the early years of the Odinic Rite Deutschland played a certain role in the creation of the VfgH blots, along with the Odinic Rite's Book of Blotar. Edred Thorsson, probably the most influential Asatru author worldwide, has not been directly involved with Wicca, but relates having had an "indirect connection" that made him "familiar with the workings of that system." (Edred, History of the Rune-Gild, III (The Reawakening of the Gild 1980-2005), 27). For his instrumental The Book of Troth he invented the Hammer ritual, which has definite parallels to Wiccan practices. It is a form of calling the four directions and hallowing the circle for a blot used by many Asatru groups, including Scandinavian ones. 
result from their shared background in Western ritual and ceremonial magic, ${ }^{93}$ or even possibly from German neo-Pagan influences on Wicca - especially since Germanic pre-Christian religion as a seasonal religion of nature is older than the Wicca movement itself. Some early 2oth century German Faithlers already celebrated the seasonal sun cycle and saw Eddic myths as reflections of nature and fertility, and combined these with a belief in the unity of the Germanic race with its nature. ${ }^{94}$

In everyday practice, reflections on the origin of Asatru blots play a fairly marginal role. The question of codifying Asatru rituals is also a point of discussion. Many groups and individuals welcome the lack of sources on 'Germanic' rituals, as it gives them an opportunity to freely create practices of worship that fit contemporary needs and predilections. In Norwegian and Danish Asatru, codification only took place when the process of institutionalization and professionalization i.e., the application for state recognition, required it. ${ }^{95}$

Closely related to this question of codification is the issue of priesthood within Germanic Neopaganism. Three main models of organization have been in place since the early 2oth century. The first is an initiatory model, which implies a Masonic system of ascending degrees. It was practiced in, or propagated by, Ariosophic groups and related secret societies or lodges in the early

93 The basic Wicca ritual as it was constructed by Gerald Gardner is based on Aleister Crowley's Book of Shadows. For the influence of Crowley on Gardner and Wicca see Hutton, The Triumph of the Moon, 216-223. In an article about the origin of Danish Forn Siðr's blot Martin P. Hansen, "Blótets liturgi, før og nu" points to this parallel as well. Crowley's ideas were also instrumental for the modern occult revival, which Ariosophy and Germanic Faith, theosophy, and a number of occult orders, such as the sex-magic O.T.O., are part of (cf. Bogdan, "The Influence of Aleister Crowley on Gerald Gardner and the Early Witchcraft Movement").

94 This is illustrated in the 'sacred dramas' written by Ernst Wachler and Ludwig Fahrenkrog for the outdoor stage at Harzer Bergtheater, which also served as a location for ritual activities of the GGG. Here, the seasonal cycle, along with the hammer and swastika symbols (both read as sexually charged symbols of fertility and a violent national and racial rebirth) were frequently used, cf. Ludwig Fahrenkrog, Baldur (Stuttgart: Greiner und Pfeiffer, 1908), Wölund (Stuttgart: Greiner und Pfeiffer, 1914), Ernst Wachler, Walpurgis. Ein Festspiel zur Frühlingsfeier (Leipzig: C.F. Amelangs Verlag, 1903), Mittsommer. Trauerspiel mit Chören für die Bühne unter freiem Himmel (Munich/Leipzig: Georg Müller, 1905), Schnurbein, "Religiöse Ikonographie - religiöse Mission. Das völkische Weihespiel um 1910." For a more in depth discussion see Chapter 9.

95 Forn Siðr's first application was turned down because its ritual structures, especially those for public services, such as marriages, were not clear enough. See Forn Sidr's homepage: http://www.fornsidr.dk/om-forn-sidr/godkendelsesforloebet, last accessed February 26, 2014. 
2oth century, and later the Goden-Orden, as well as the Armanen-Orden in Germany. Today, Edred Thorsson's Rune Gild follows a similar initiatory pattern, which is otherwise not very prominent in contemporary Germanic Neopaganism. ${ }^{96}$

The second type implies a church-like structure, with an officially appointed clergy ('Gode' or 'Godi' for male, 'Gydja' for female), an official religious leader comparable to a bishop ('Allsherjargodi'), and at least plans for the erection of hofs. Ludwig Fahrenkrog's ideas about Germanic ritual practices and temple buildings at alleged sacred sites in Germany dating from the early 2oth century can be included in this category. ${ }^{97}$ Today, the Germanische Glaubensgemeinschaft continues Fahrenkrog's tradition not only in the name of its association, but also in its model of priesthood. ${ }^{98}$ Iceland is the only country that has a functioning system of an officially appointed clergy and a formal election process for the Allsherjargodi as the national religious leader. The most influential American groups, The Troth and the AFA, do not have any national religious leaders, but have both introduced clergy training programs. ${ }^{99}$ Swedish Samfundet Forn Sed established a training program for Goder and Gydjer in 2010 to ensure the quality of spiritual services offered. ${ }^{100}$

In other respects, Samfundet Forn Sed, Danish Forn Siðr, Norwegian Bifrost, Foreningen Forn Sed, along with the German Eldaring and $\mathrm{VfgH}$, are organized according to the third, least-structured model. It follows an idea formulated already in the early 2oth century by Otto Sigfrid Reuter (Deutschgläubige Gemeinschaft), who completely rejected a formal priesthood as well as a formalized creed or temple-buildings. ${ }^{101}$ In the contemporary groups previously mentioned, the national organizations function as umbrellas or networks

96 An exception is Theodism, which claims to reconstruct the full Anglo-Saxon social hierarchy, including the model of sacred kingship, cf. Lord, "The Evolution of Theodish Belief. Part I"; The Way of the Heathen.

97 Cf. Puschner 2001, 252.

98 However, its leader Géza von Neményi's claim to the status of Allsherjargodi has not been recognized by any other Asatru group in Germany and has given rise to much resistance and ridicule, cf. Pöhlmann, "Streit um Heiden-Papst - Géza von Neményi erhebt Führungsanspruch innerhalb des Neuheidentums."

99 http://www.thetroth.org/index.php? page=clergyprograms\&title=Clergy \%20 Program\%2o|\%2oThe\%2oTroth\&css=style2\&pagestyle=mid; http://www.runestone.org/ about-the-afa/clergy-program.html, last accessed March 19, 2014.

100 Cf. http://www.samfundetfornsed.se/om-samfundet-1282525, last accessed March 19, 2014. See also Sveriges Asatrosamfund, "Snart är de nya stadgarna här!," 5 f.

101 Although the structure Reuter imagined was similar to contemporary groups,' his reasoning was not. For him, the creation of structured "teaching communities" (Lehrgemeinschaften) 
allowing anyone who wishes to conduct a ritual to do so. ${ }^{102}$ Associated regional or special interest blotgroups may institute their own rules and practices. As state-registered associations (e.g., German Eldaring and $\mathrm{VfgH}$ ) or official religious communities (e.g., Scandinavian groups), they are chaired by an elected board, usually comprising of at least a chairperson, their deputy, a secretary, and a treasurer, all of whom have administrative functions, but no religious authority. ${ }^{103}$

The existence of a formal priesthood notwithstanding, Asatru has another, more informal system of religious specialists: members who engage in rune magic or a neo-shamanic practice called seid (sometimes spelled Sejd, seidh, seidhr, or seiðr). Both remain contested in Asatru and Odinism. Some see them as dishonorable, inauthentic, foreign, modern occultist, or esoteric practices associated with Wicca. Others consider the study of runic or seid practices the core of their religious activity. Rune magic, and to a lesser degree and more recently seid, can be seen as Germanic Neopaganism's unique contributions to the modern occult and esoteric revival. They have also become popular practices outside Asatru, and thus their history, context, and present status deserve particular attention here.

The roots of modern esoteric runology are found in Guido List's visions. ${ }^{104}$ He 'revealed' the runes as the sacred original language of mankind, or rather of

served to create a "pure racial community." Cf. Puschner, Die Völkische Bewegung im wilhelminischen Deutschland, $252 \mathrm{f}$.

102 The problem in these groups is more often the lack of individuals willing to and interested in accepting the responsibility for designing and conducting a ritual. In practice, this leads to the same people leading rituals and thus taking on an informal role as religious specialists.

103 Also in this respect, the German Nornirs \&tt deviates most. They decided against registering as a society, so that they could institute a principle of consensus and not of elected representatives, cf. Gründer, Blótgemeinschaften, 217.

104 The runes are an alphabet used for inscriptions between the 2nd and 14th century, mainly in southern Scandinavia. The older rune-row (called futhark, after its first six letters) consisted of 24 letters, the younger futhark of 16. Most inscriptions date from the Viking Age. There are some hints in the sagas that runes were used for magic purposes, but not much is known about these practices, if indeed they ever existed. (For a comprehensive overview of theories and scholarship on runes cf. Klaus Düwel, Runenkunde, 4. ed., Sammlung Metzler (Stuttgart: Metzler, 2004)). The idea that 'Teutons' actually 'cast runes' for divinatory purposes originates in a specific reading of Section 10 in Tacitus' Germania about omens and casting of lots. As the first runic inscriptions to have been found date considerably later, it is not very likely that Tacitus (if his account itself is actually accurate and not just a projection of Roman practices onto the Northern Barbarians) really referred to the runes here. In the modern era, the idea of the runes' magic properties was first taken 
its spiritual leaders, the Aryans, and as expressions of the highest cosmic powers guiding the ancient 'Ario-Germans.' 105 In his most influential work, Das Geheimnis der Runen (The Secret of the Runes, 1908), List created an allegedly ancient eighteen-letter runic alphabet, and assigned each rune a verse of Odin's spells in the Eddic lay Hávamál. ${ }^{106}$ For List, this runic system contained the essence of Ario-Germanic wisdom. He claimed that it had been secretly transmitted through the 'dark ages' of Christianity and racial mixing via clandestine brotherhoods: medieval guilds of Masons, Templars, witchcraft, and also the Icelandic skalds, who allegedly preserved the ancient German mythology, albeit in Icelandic translation. The idea that runic wisdom was concealed in various symbolic systems that could be decoded by way of his intuition allowed List to identify traces of this ancient knowledge in all kinds of later sources, be they Christian, heretic, philosophical, or symbolic.

List's system fit with common occult practices of analogical thinking, and proved easily applicable to various systems of esoteric classification. List and Lanz von Liebenfels' follower Rudolf John Gorsleben applied them to astrology, ${ }^{107}$ while the Ariosophists Friedrich Bernhard Marby and Siegfried Adolf Kummer created runic gymnastics, or 'rune-yoga.' It bears repeating that such ideas regarding the secret functions of the runes cannot easily be separated from the underlying assumption that cosmic runic energies speak only to those of "pure Aryan blood." It is thus the Aryan's obligation to preserve this

up by Renaissance runologist Johannes Bureus, who interpreted them and Norse mythology in the light of Rosicrucian, cabbalistic, astrological, and hermetic theories.

105 Schnurbein, Religion als Kulturkritik, 92f; Ulrich Hunger, Die Runenkunde im Dritten Reich. Ein Beitrag zur Wissenschafts - und Ideologiegeschichte des Nationalsozialismus (Frankfurt a.M.: Lang, 1984), $316 f$.

106 This section, sometimes also referred to as Rúnatal (Rune-poem), tells of Odin hanging from a tree for nine nights, "finding runes" and listing 18 "songs of power," which describe, for example, how enemies can be beaten and women's desire awakened. It is still debated if this actually refers to the letters or merely to 'secrets,' the literal meaning of the word 'runa.'

107 Rudolf John Gorsleben, Hoch-Zeit der Menschheit. Das Welt-Gesetz der Drei oder Entstehen - Sein - Vergehen in Ursprache - Urschrift - Urglaube. Aus den Runen geschöpft (Leipzig: Koehler \& Amelang, 1930) designed an astrological chart he called "Tyr-Kreis," claiming that the German word for the zodiac, "Tier-Kreis" (meaning "animal circle"), is a distortion of the original meaning, which refers to the Nordic god Tyr. Sigrun von Schlichting and Géza von Neményi followed this idea and the theory is fairly widespread in Asatru circles (cf. Schnurbein, Religion als Kulturkritik, 47; Valdemar Ravn, "Interview med Géza von Neményi den Tyske Allherjargode," Valravn. Hedensk tidskrift om samfund og kultur 13 (2005), 11). A Google search for "Tyr-Kreis" gave 41,300 hits in March 2014. 
purity of the blood, a task in which runic practices are an indispensable tool. This attitude is summarized in Guido von List's "mystical interpretation" of the ka-rune:"Dein Blut, Dein höchstes Gut" (Yourblood, yourhighest possession). ${ }^{108}$ Gorsleben embedded his rune esoteric in a theory of "racial consciousness and selective racial breeding," claiming that "God and race are one."109 Marby, and later his post-war publisher, Rudolf Arnold Spieth, were both adamant that his "Rassische Gymnastik" (racial gymnastics) was to be understood as an "Aufrassungsweg" (path of racial improvement), which was to be strictly reserved for members of the "Germanic Race."110

If the runes were discredited as viable icons after the fall of Hitler's regime in 1945 , it was not due to rune esotericists' racial theories, but rather to the extensive use the National Socialist state had made of some 'Germanic' symbols, in particular the swastika, ${ }^{111}$ and specific runes such as the double sig-rune for the ss. It did not take long before an attempt was made to rehabilitate the "Armanen" rune system and purge it of its more overt racial implications. In 1955, Karl Spiesberger (1904-1992), a member of the occult order Fraternitas Saturni, started publishing on rune divination and rune exercises while teaching workshops using Gorsleben's, Marby's, Kummer's and most of all List's works as points of reference. ${ }^{112} \mathrm{He}$ distanced himself from "distortions of runic knowledge by race fanatics" and thought it important to separate the "everlasting wheat grain of eternal values" from the racist chaff. ${ }^{113}$ At the same time, he carefully omitted mentioning that the racist content of rune knowledge was actually propagated by the 'masters' of esoteric runology themselves, and could not just be attributed to misuse by National Socialists.

The works by Spiesberger, List, Marby and Gorsleben strongly influenced the rune practices within the German Armanen-Orden. Internationally, the post-war runic revival was spearheaded mainly through the activities of Stephen Flowers, alias Edred Thorsson. He founded his initiatory Rune Gild in 1980 and launched three influential books on rune esoteric. ${ }^{114}$ Flowers/

\footnotetext{
108 List, The Secret of the Runes, 53.

109 All quotes from the Table of Contents in Gorsleben, Hoch-Zeit der Menschheit.

110 See http://spiethverlag.de, last accessed September 16, 2014.

111 It should be noted, however, that the swastika played a central role as a sign of racial consciousness and life energy in Ariosophy as well.

112 Karl Spiesberger, Runenmagie. Handbuch der Runenkunde (Berlin: Schikowski, 1955).

113 Ibid., preface.

114 Thorsson, Runelore. A Handbook of Esoteric Runology; Rune Might. Secret Practices of the German Rune Magicians (St. Paul, MN: Llewellyn, 1989); Northern Magic. Rune Mysteries \& Shamanism (St. Paul, MN: Llewellyn, 1998).
} 
Thorsson has been ambiguous about his being influenced by Ariosophy. On the one hand, we know he discovered Spiesberger's writings in $1974,{ }^{115}$ and that like Spiesberger, he strongly denounced the abuse of runic symbolism by National Socialism. However, he claims to offer a more historically sound take on rune divination beyond early 20 th century German rune magic, e.g., by basing his theories not on List's invented 18-part rune row, but on the older, historically informed 24-part alphabet. This, along with his academic background, convinced Heathens worldwide that his rejection of racial readings of the runes was honest and serious, and that his esoteric teachings were based on solid historical knowledge. ${ }^{116}$ Nevertheless, in acknowledging the help extended to him by Adolf and Sigrun Schleipfer, of the racial-religious Armanen-Orden, Thorsson's second book, Runelore, indicated that he might owe more to Ariosophy than what was initially understood. ${ }^{117}$ In addition to quoting academic literature in Rune Might, he recognizes List and Marby as authors on runology who "shine out above all the rest,"118 and goes on to present the Armanen-Orden as a contemporary bearer of List's runic knowledge. ${ }^{119}$ In 1988, Flowers/Thorsson published an English translation of List's The Secret of the Runes, and thus initiated a surge of interest for Ariosophy and the 'Armanen-runes' within Asatru in the United States. ${ }^{120}$ Up until 2012, his publishing company Runa Raven Press distributed his translations of other works by List, as well as by the Ariosophists Lanz von Liebenfels, Siegfried Adolf Kummer, and Rudolf von Sebottendorf. ${ }^{121}$

This runic revival was further supported by a number of others. A former member of Thorsson's Rune Gild, the Dutch-British Asatruer Freya Aswynn, published the essence of her runic teachings in 1990 under the title The Leaves

115 Edred, History of the Rune-Gild, III (The Reawakening of the Gild 1980-2005), 28.

116 Cf. Interview with six members of Nornirs Ætt. My interview partners from Nornirs Ætt mentioned that this initial positive impression was soon disappointed when Thorsson's uncritical references to Ariosophy became obvious.

117 Thorsson, Runelore. A Handbook of Esoteric Runology, 'Acknowledgements.'

118 Rune Might. Secret Practices of the German Rune Magicians, xiii.

119 Ibid., 29f.

120 Several American Asatruers mentioned being "great fans of List." A Google-search on the key words 'Armanen-runes' in November 2011 gave 4,280,00o hits.

121 The press was closed down in fall 2012. https://www.facebook.com/Asatru.Folk.Assembly/ posts/443338919052337. Runa Raven Press is currently listed as a branch of the occultist Magus Books, http://www.magusbooks.com/category/RUNA-Raven. Books formerly distributed by Runa Raven Press by Thorsson/Flowers and others can now be found on www .arktos.com. For information about the New Right publishing company Arktos see Carter, "Packaging Hate - the New Right Publishing Network." 
of Yggdrasil. ${ }^{122}$ The same year, in Teutonic Magic, Kveldulf Gundarsson/ Stephan Grundy harked back to List's/Thorsson's rune esoteric. While praising List's The Secret of the Runes for its intense depth of understanding and brilliance of approach, he conceded that the text contains some "downright bizarre" elements, ${ }^{123}$ although he failed to mention the racial theories behind List's work.

Rune divination, incantation, magic and rune yoga thus became widespread practices in Germanic Neopaganism. Up until today, Thorsson's work on runes continues to be hugely influential, if not the ultimate authority on the subject. ${ }^{124}$ At the same time, there is currently a growing resistance to his work's dominance. Quite a few European Asatruers, as well as Pagans and esotericists of other persuasions, have tried to break Thorsson's monopoly and have written their own versions of rune books. ${ }^{125}$ Authors affiliated with the Swedish network for shamanism, Yggdrasil, started their own tradition of rune esoteric in the 1980s, referencing not only Thorsson but also Renaissance scholar Johannes Bureus. ${ }^{126}$ Due to the entanglement of rune magic with occultism, a greater skepticism has taken over within Asatru in recent years, especially in

122 Aswynn, Leaves of Yggdrasil. A second revised edition appeared in 2002 under the title Northern Mysteries and Magic.

123 Gundarsson, Teutonic Magic. The Magical and Spiritual Practices of the Germanic People, 180.

124 Most Asatru groups will at least list some of Thorsson's books on their reference lists, and many of my interview partners in all countries had them in their bookshelves.

125 Amongst them are Géza v. Neményi, Heilige Runen. Zauberzeichen des Nordens (Berlin: Ullstein, 2004), Jan Fries, Helrunar. Ein Handbuch der Runenmagie (Bad Ischl: Ananael, 1997), Igor Warneck, Ruf der Runen. Eine Einführung in die Welt der Runen (Darmstadt: Schirner, 2005), and GardenStone, Germanische Magie.

126 Their approaches distinguish themselves by using the theory of Sigurd Agrell, Runornas talmystik och dess antika förebild (Lund: Gleerup, 1927) (1881-1937), a professor at the University of Lund, Sweden, who in the early 1900 s forwarded the speculative theory that the first letter of the runic alphabet, the 'fe'-rune, belonged at its end, so that the rune row should actually be called “uthark," cf. Gregorius, Modern Asatro, 256. Meanwhile, Flowers/ Thorsson has discovered and translated Bureus' Adalruna, (Stephen Flowers, Johannes Bureus and Adalruna (Smithville, Tx: Runa-Raven Press, 1998)). The "uthark" theory in its esoteric form is spread to an English speaking audience by Thomas Karlsson, head of the Swedish occult order Dragon Rouge, who combined Agrell's theories with his own thoughts on magic in Thomas Karlsson, Uthark. Nightside of the Runes (Sundbyberg: Ouroboros Productions, 2002). Through his occult order Dragon Rouge, Karlsson's work seems to have a certain influence in international esoteric circles connecting him with Edred Thorsson/Stephen Flowers (cf. Edred, History of the Rune-Gild, III (The Reawakening of the Gild 1980-2005), 159), the German occultists and Asatruers. 
Germany and Scandinavia. ${ }^{127}$ Most groups today take an ambivalent position. They use runic practices sparsely in their communal rituals, but allow for the practice of rune and other magic by individuals. ${ }^{128}$

Runic quests are often accompanied by methods Germanic Neopagans borrow from neo-shamanism, for example utiseta (sitting out). While the name of this practice is taken from saga literature, it is more related to neo-shamanic 'vision quests,' in which solitude in nature (mainly at night) is hoped to facilitate communication with gods or spirits. ${ }^{129}$ Shamanism has probably been the single most popular magic technique within the alternative religious and esoteric movement; self-help books, seminars, and lectures in the 1970s propagated its practices of expanded or extraordinary states of consciousness, meditation, and healing. Moreover, this neo-shamanic wave was "spawned by the drug culture of the 1960 s and 70 , the human potential movement, environmentalism, interests in non-Western religions, and by popular anthropology, especially the Castaneda books." ${ }^{130}$

Neo-shamanism is closely connected to American and European leftist counter-culture, which is one reason it is regarded with suspicion by some Germanic Neopagans. However, this did not stop several groups and individuals in the 1980 s from investigating the possibilities of (re-)creating a 'Nordic' or 'Germanic' form of shamanism. In reference to a (usually despised) practice of magic and divination mentioned in medieval Icelandic texts such as the Sagas of the Icelanders, as well as in the Eddas, it is frequently referred to as seid or seiðr. In order to develop a modern version of seid from medieval sources, and on the grounds of 'empirical testing,' the Swedish network of shamanism, Yggdrasil, based their reconstructive efforts mainly on two Swedish scholars' works: Dag Strömbäck's famous study Sejd (1935) and Folke Ström’s

\footnotetext{
127 Gregorius, Modern Asatro, 264f.

128 Cf. Correspondence with Kurt Oertel (Eldaring).

129 Cf. Jonsson, "Ásatrú á Íslandi við upphaf 21. aldar," 179; Blain, Nine Worlds of Seid-Magic, 63.

130 Jane M. Atkinson, "Shamanisms Today," Annual Review of Anthropology 21 (1992), 322. Carlos Castaneda was an American anthropologist who wrote several books about his encounters with the Mexican shaman Don Juan. The accounts were later revealed as fictive, but had a great impact nevertheless. Another anthropologist, Michael Harner, who had done field-work in South America in the 1950s, extracted a method which he called "core shamanism" from various cultures and has taught it in workshops all around North America and Europe since the 1980s. Cf. Merete Demant Jakobsen, Shamanism. Traditional and Contemporary Approaches to the Mastery of Spirits and Healing (New York/Oxford: Berghahn Books, 1999), 160; Mihály Hoppál, "Urban Shamans. A Cultural Revival," in Studies on Shamanism, ed. Anna-Leena Siikala and Mihály Hoppál (Helsinki/Budapest: Finnish Anthropological Society, 1992), 200.
} 
1967 history of Norse religions, Nordisk hedendom (Norse Paganism). ${ }^{131}$ Another attempt to revive seid was undertaken by Stephen Flowers/Edred Thorsson, who combined runic practices and shamanism in his book Northern Magic (1998). Here, he linked Norse shamanism to the genetic heritage of the Germanic peoples, or "Aryans," and suggested that Norse shamanism should be practiced as an expression of an "ancestral path."132 His former student and prominent Troth member, Kveldulf Gundarsson/Stephan Grundy, further developed this combination of runic and shamanic activities in the abovementioned Teutonic Magic ${ }^{133}$ and popularized them through his novel Attila's Treasure. ${ }^{134}$ Finally, Troth member and fantasy author Diana Paxson and her group Hrafnar in Berkeley, California developed a particular form of seid: oracular seid, or spae, in which a seidwoman or man (völva) go into a trance with the aid of drumming and chanting, and then answer participants' questions with the help of images they encounter in their trance. ${ }^{135}$ Furthermore, it is

131 Cf. Ström, Nordisk hedendom; Dag Strömbäck, Seijd. Textstudier i Nordisk Religionshistoria (Stockholm/Copenhagen: Levin \& Munksgaard, 1935). Lindqvist, Shamanic Performances on the Urban Scene. Neo-Shamanism in Contemporary Sweden, 39, 133ff, describes the history of the ritual in Yggdrasil, from its initial beginnings in a small circle of friends. She evaluates this development as a strategy of authentification. According to her, the material and research on seiðr give it an authentic feel. At the same time, the scarce material leaves enough space for imagination and improvisation in the creation of a ritual appropriate to the time and one's own needs. Although Yggdrasil by now is defunct, its method of seid and variations of it have survived and entered into at least parts of Asatru practice. Carl Johan Rehbinder head of Sveriges Asatrosamfund between 2000 and 2003 and also initiator of Ratatosk (another network for Nordic Shamanism), maintained in an interview that the Nordic Way is steeped in shamanistic attitudes and practices, cf. Valdemar Ravn, "Interview med Carl Johan Rehbinder, en svensk hedning," Valravn. Hedensk tidskrift om samfund og kultur 15 (2005), 7. However, other leading members of Sveriges Asatrosamfund/Samfundet Forn Sed are careful to point out that seid is not considered an official group activity, although individuals practice it and many of the groups' activists over the years have had a "seid perspective" on Asatru. "Interview med Mikael Perman."

132 Thorsson, Northern Magic. Rune Mysteries \& Shamanism, xii and 4.

133 Gundarsson, Teutonic Magic. The Magical and Spiritual Practices of the Germanic People.

134 Grundy, Attila's Treasure. Grundy/Gundarsson however rejects the term seid for these magic practices due to its negative valuation in saga literature. He suggests using 'spae' for these divinatory activities - a practice which has been followed by the German Eldaring, cf. Correspondence with Stephan Grundy (The Troth), 2011; Correspondence with Kurt Oertel (Eldaring), see also Blain, Nine Worlds of Seid-Magic, 59, 97.

135 This oracular seid has been made particularly popular by Jenny Blain, a member of The Troth and professor of anthropology at Sheffield Hallam University in England, who investigated her own and others' practices of seid as well as its basis in medieval sources in her Nine Worlds of Seid-Magic. 
quite common for Asatruers to attend seminars on "core shamanism" and experiment with combining these techniques with their own understandings of Norse sources on seiðr. ${ }^{136}$ Bil Linzie, an Asatruer in the American SouthWest, was taught shamanic practices by Sami neo-shaman Ailo Gaup. ${ }^{137}$ In Scandinavia as well as in Germany, Annette Høst reaches a broader Asatru audience through courses at her Scandinavian Center for Shamanic Studies. ${ }^{138}$

Although seid has established itself ever more as an important practice, its status remains ambiguous and precarious. By some, it is perceived as dangerous and fear-inspiring, ${ }^{139}$ others are suspicious because of its sexual overtones and gender-bending associations. ${ }^{140}$ For these critics of seid, such 'perverse' activities appear incompatible with a Germanic worldview based on honor and heroism. There is, however, another concern which even some practitioners of seid have, and which applies not so much to seid as such, but to its combination with neo-shamanism. American seid specialist Bil Linzie puts it this way:

Neo-shamanism in the past decade is resulting in significant changes in the heathen Germanic worldview. These changes are really a distraction and a movement away from Ásatrú as a reconstructed religion, and even though many claim to have found support in the lore for something similar to neo-shamanism, the fact is that the worldview presented by neoshamanic practitioners remains mostly inconsistant [sic] with the ancient worldview. ${ }^{141}$

The disputes within Asatru about the authenticity of practices like rune magic or seid indicate a concern with what some call the need to preserve the 'purity' of Asatru. This leads to questions about the sources Asatruers base their ideas on, how they deal with the precarious status of these sources, and how they deal with the academic theories developed around them. These questions will be addressed in Chapter 8 . The debates around authenticity return us to our previous observation: that Asatru prides itself on being a non-dogmatic religion that does not prescribe articles of faith, rules, or regulations. Our

\footnotetext{
136 See for example Correspondence with Kurt Oertel (Eldaring).

137 Blain, Nine Worlds of Seid-Magic, 118.

138 See http://www.shamanism.dk/, last accessed March 20, 2014. Cf. also Chapter 7.

139 Interview Q.

140 Interview K. For a fuller discussion of these aspects of seid cf. Chapter 7.

141 Bil Linzie, "Germanic Spirituality," Temple of Our Heathen Gods, http://heathengods .com/library/bil_linzie/germanic_spirituality.pdf, last accessed December o6, 2011, 39.
} 
discussion of Germanic Neopagan beliefs and practices in this chapter has indeed shown that Asatru lacks some characteristics considered typical for religions. As Piotr Wiench so aptly notes with regard to Central and Eastern European Neopaganism, it does not have an "elaborate system of religious and moral thought, a mature set of doctrines, [or] refined theology," nor does it offer institutional support to individuals. ${ }^{142}$ Instead, many Heathens perceive their faith not just as a spiritual path but also a holistic worldview: religion, culture, and social practices are unified, expressing Germanic cultural or ethnic essence in a specific way. In other words, there is a tendency to focus more on discourses of identity and ethnicity than on religious matters, and to imbue dimensions such as ethnic identity with spiritual meaning. Such perceptions of Pagan religion overlap with political worldviews, a fact that fuels vivid controversies about the 'ethnic' character of Asatru and Germanic Neopaganism's perception of religion - two contested fields which will be analyzed in detail in the following chapters.

142 Piotr Wiench, "A Postcolonial Key to Understanding Central and Eastern European Neopaganisms," in Modern Pagan and Native Faith Movements in Central and Eastern Europe, ed. Scott Simpson and Kaarina Aitamurto, Studies in Contemporary and Historical Paganism (Durham: Acumen, 2013), 13. 